\title{
Modulation of expression and activity of cytochrome P450s and alteration of praziquantel kinetics during murine schistosomiasis
}

\author{
Mara A Gotardo, Juliana T Hyssa, Renato S Carvalho, Rosangela R De-Carvalho, \\ Luciana S Gueiros, Carolina M Siqueira, Marcia Sarpa, Ana Cecilia AX De-Oliveira/ ${ }^{+}$, \\ Francisco JR Paumgartten
}

Laboratório de Toxicologia Ambiental, Departamento de Ciências Biológicas, Escola Nacional de Saúde Pública, Fundação Oswaldo Cruz-Fiocruz, Av. Brasil 4036, 21040-361 Rio de Janeiro, RJ, Brasil

In this study, we investigated the expression and activity of liver cytochrome P450s (CYPS) and praziquantel (PZQ) kinetics in mice infected with Schistosoma mansoni. Swiss Webster (SW) mice of both genders were infected (100 cercariae) on postnatal day 10 and killed on post-infection days (PIDs) 30 or 55. Non-infected mice of the same age and sex served as controls. Regardless of mouse sex, infection depressed the activities of CYPIA [ethoxy/ methoxy-resorufin-O-dealkylases (EROD/MROD)], 2B9/10 [pentoxy/benzyloxy-resorufin-O-dealkylases (PROD, $B R O D)], 2 E 1$ [p-nitrophenol-hydroxylase (PNPH)] and $3 A 11$ [erythromycin N-demethylase (END)] on PID 55 but not on PID 30. On PID 55, infection decreased liver CYP $m R$ NA levels (real-time reverse transcription-polymerase chain reaction). On PID 30, whereas $m R N A$ levels remained unaltered in males, they were depressed in females. Plasma PZQ (200 and $400 \mathrm{mg} / \mathrm{kg}$ body weight intraperitoneally) levels were measured (high-performance liquid chromatography) at different post-treatment intervals. In males and females, infection delayed the PZQ clearance on PID 55, but not on PID 30. Therefore, it can be concluded that schistosomiasis down-modulated CYP expression and activity and delayed PZQ clearance on PID 55, when a great number of parasite eggs were lodged in the liver. On PID 30, when egg-laying was initiated by the worms, no change of CYP expression and activity was found, except for a depression of CYPIA2 and $3 A 11$ mRNAs in female mice.

Key words: Schistosoma mansoni - xenobiotic metabolism - pharmacokinetics - cytochrome P450

Schistosomiasis is a tropical disease that affects more than 200 million people in Africa, Asia, South America and some Caribbean islands. It is caused by flatworms of the genus Schistosoma, the life cycle of which involves a sexual reproduction stage in humans or other vertebrate hosts and an asexual multiplication stage in freshwater snails (Gryseels et al. 2006). The acute phase of human schistosomiasis is asymptomatic or produces only slight and transient symptomatology such as the itching of the area where the parasites penetrate the skin, malaise, fever and eosinophilia. In chronic infections, however, more severe morbidity may eventually arise from the inflammatory response to parasite eggs retained in the liver and intestines (infections by Schistosoma mansoni, Schistosoma japonicum, Schistosoma intercalatum and Schistosoma mekongi) or in the urinary tract (Schistosoma haematobium) (Gryseels et al. 2006). Schistosomiasis of the urinary tract is endemic in the African continent and in the Middle East where it has been associated with a higher incidence of bladder cancer (Fried et al. 2010).

Because the progress of $S$. mansoni infection observed in the mouse is similar to that in humans to some extent, murine models have been widely used to

Financial support: CNPq, INOVA-ENSP (ENSP/FIOCRUZ) FJRP, LSG, CMS and JTH were recipients of fellowships (CNPq). + Corresponding author: ana.oliveira@ensp.fiocruz.br

Received 6 September 2010

Accepted 8 December 2010 investigate the pathophysiology of schistosomiasis. In experimentally infected mice, S. mansoni matures over a five-week period and the egg laying period begins approximately 30 days after infection (Fidalgo-Neto et al. 2004). If the infection continues after this time, granulomas are formed around the schistosome eggs harboured in the liver parenchyma. Depending on the duration of infection and the accumulation of eggs in the liver, hepatosplenomegaly, hepatocellular fibrosis and portal vein hypertension may eventually occur.

It has been reported that $S$. mansoni infection markedly depresses the activities and levels of cytochrome P450s (CYPs) in the mouse liver (Cha \& Edwards 1976, Mostafa et al. 1984, Sheweita et al. 1998, Conte et al. 2007). The decline of CYP activities during schistosomiasis apparently results from the inflammatory response to the parasite eggs deposited in the liver, because no change of monooxygenase activities was noted in athymic nude mice (Cha et al. 1980a) or in infected mice with cercariae of only one sex (Cha et al. 1980b).

The effects of early S. mansoni infection on the activity of CYPs are less clear. In contrast to the generalized depression of CYP activities observed at more advanced phases of murine schistosomiasis, it was found through the studies in male BALB/c mice that there is an enhanced activity of hepatic monooxygenases 33 days after infection (El-Bassiouni et al. 1984, Mostafa et al. 1984, Sheweita et al. 1998). In Swiss Webster (SW) and DBA-2 mice of both sexes, however, Manhães-Rocha et al. (2005) demonstrated that CYP levels and activities 
remained unaltered on post-infection day (PID) 15, when parasites were still sexually immature and egg-laying had not yet been initiated. On PID 30, when very few eggs, if any, were found in the liver, the authors noted only minor alterations of monooxygenase activities that were gender- and strain-specific to the mouse (ManhãesRocha et al. 2005).

This study investigated the effects of early PID 30 and more advanced (PID 55) stages of S. mansoni infection on the mRNA levels and catalytic activities of CYPs in the liver of male and female SW mice. Additionally, the effects of schistosomiasis on the kinetics and toxicity of praziquantel (PZQ) were examined. PZQ is currently the antihelminthic drug of choice for treating schistosomiasis and other trematode infections.

\section{SUBJECTS, MATERIALS AND METHODS}

Animals - Specific pathogen-free SW mice of both genders from the Oswaldo Cruz Foundation (FIOCRUZ) breeding stock were used. Mice were housed in standard plastic cages with stainless steel coverlids and wood shavings as bedding. The temperature $\left(23 \pm 2^{\circ} \mathrm{C}\right)$, humidity $(70 \pm 5 \%)$ and photoperiod (lights on from 8:00 am-8:00 pm) were controlled in the animal facilities. Tap water and a commercial diet for rats and mice (Nuvital CR1, Nuvilab ${ }^{\circledR}$, Curitiba PR, Brazil) were provided ad libitum. Experiments were conducted in accordance with Brazilian animal protection and welfare laws and the study protocol was approved by the Ethics Committee on the Use of Animals-Fiocruz.

Parasites and infection - Mice were infected with a Belo Horizonte isolate of $S$. mansoni as described previously by Fidalgo-Neto et al. (2004). Briefly, 10-day old pups were transferred to Petri dishes $(5 \mathrm{~cm}$ in diameter, 1 pup per dish) containing $3 \mathrm{~mL}$ of dechlorinated water with 100 recently-shed cercariae. Pups were kept warm by $60-\mathrm{W}$ tungsten lamps located close to the Petri dishes while the infection took place. Under these conditions, the pups' tail and paws as well as the entire ventral part of their bodies were exposed to cercarial penetration for $20 \mathrm{~min}$. Immediately after this period, all pups were returned to the cage of their mothers. A few drops of Lugol's iodine solution were then added to each dish and the number of cercariae that failed to penetrate the mouse skin (i.e., separated cercarial heads and intact cercariae) was counted under a stereomicroscope. In this study, skin penetration by the cercariae ranged from 98 $100 \%$. Uninfected control (CTRL) (sham-treated) mice were treated by the same methods as for infected mice, with the absence of cercariae in the Petri dish water.

In some infected mice the number of parasite eggs trapped in the liver was counted on PIDs 30 and 55. Eggs were recovered and counted according to previously described methods (Cheever 1968, Fidalgo-Neto et al. 2004). Briefly, livers were excised, placed into conical flasks and digested with a $5 \%$ potassium hydroxide solution at $37^{\circ} \mathrm{C}$ for $16 \mathrm{~h}$. Aliquots $(50 \mu \mathrm{L})$ of the digests were then placed onto microscope slides underneath a cover slip and the eggs were counted with a 100X magnification. Three aliquots from each digest were examined.
Preparation of liver microsomal fraction - Infected mice and their age and sex-matched CTRL mice were sacrificed by cervical dislocation on PIDs 30 and 55 (i.e., when they were 40 and 65 days old), respectively. Immediately after the sacrifice, the livers were removed, freed from fat and extra tissue, weighed and frozen in liquid nitrogen until further use. Hepatic microsomes were prepared as described by De-Oliveira et al. (1999) and the microsomal protein concentration was determined by the method of Bradford (Bradford 1976) using bovine serum albumin as the standard. A piece of frozen liver was used for mRNA extraction.

Quantification of CYP1A2, 2E1 and 3A11 mRNAs Quantification of m-RNA levels was performed by realtime reverse transcription-polymerase chain reaction as follows. RNA from the livers of infected and CTRL mice age-paired controls was extracted using the Trizol ${ }^{\mathbb{}}$ reagent according to the manufacturer's instructions. The RNA was quantified in a Nanodrop ${ }^{\circledR}$ spectrophotometer and $3 \mu \mathrm{g}$ was used as template for cDNA synthesis, using the Superscript II $^{\circledR}$ system (Invitrogen ${ }^{\circledR}$ ) and oligo DT primers $\left(\right.$ Promega $\left.^{\circledR}\right)$. This reaction was conducted in a Mastercycler Gradient thermocycler $\left(\right.$ Eppendorf $\left.^{\circledR}\right)$. Relative expression of CYP450 isoforms were determined using Taqman ${ }^{\circledR}$ assays (Applied Biosystems $^{\circledR}$ ). Assays Mm00487224_m1, Mm00491127_m1 and Mm00731567 m1 were used for CYP1A2, 2E1 and $3 \mathrm{~A} 11$, respectively, and the assay $435234 \mathrm{E}$ was used for $\beta$-actin (endogenous control). Real time reactions were conducted in a 7,500 Fast Real-Time thermocycler (Applied Biosystems ${ }^{\circledR}$ ). The relative quantification of the target genes was made using the $\Delta \Delta \mathrm{Ct}$ method.

Enzyme assays - Alcoxyresorufin-O-dealkylases (XROD) - XROD were assayed using pentoxy (PROD), benzyloxy (BROD), ethoxy (EROD) and methoxy-resorufin (MROD) as substrates. XROD activities were determined as reported by Burke et al. (1985) except for the use of a nicotinamide adenine dinucleotide phosphate (NADPH) regenerating system as previously described (De-Oliveira et al. 1999). Accumulation of resorufin was measured using a spectrofluorimeter $\left(\mathrm{Shimadzu}^{\circledR}\right.$ RF 5301 PC) with excitation and emission wavelengths set at $550 \mathrm{~nm}$ and $582 \mathrm{~nm}$, respectively, and with a $5 \mathrm{~nm}$ band slit width.

p-nitrophenol-hydroxylase (PNPH) - Activity of PNPH in the mouse liver microsomal fraction was determined by the real-time kinetic method reported by Allis and Robinson (1994). The substrate ( $p$-nitrophenol) concentration was $10 \mathrm{mM}$ and microsomal protein $(0.2 \mathrm{mg})$ was added to cuvettes where the reaction took place. After $10 \mathrm{~min}$ of reaction, the absorbance was read at $480 \mathrm{~nm}$ in a Shimadzu ${ }^{\circledR}$ UV 1601 spectrophotometer. The enzyme activities were calculated using the molar coefficient $3.57 \mathrm{mM}^{-1} \mathrm{~cm}^{-1}$ (Allis \& Robinson 1994).

Erythromycin-N-demethylase (END) - END activity was measured according to the method described by Berg-Candolfi and Candolfi (1996). Briefly, microtubes containing erythromycin $(1 \mathrm{mM})$, microsomal protein $(1 \mathrm{mg})$, NADPH regenerating system, Tris buffer 
(50 mM, pH 7.4) and $\mathrm{KCl}(150 \mathrm{mM})$ up to a final volume of $1 \mathrm{~mL}$, were incubated at $37^{\circ} \mathrm{C}$ with 30 min of shaking. The reaction was terminated with the addition of $0.1 \mathrm{~mL}$ of $25 \% \mathrm{ZnSO}_{4}$. After standing in an ice-bath for $15 \mathrm{~min}$, $0.1 \mathrm{~mL}$ of saturated $\mathrm{Ba}(\mathrm{OH})_{2}$ solution was added to the tubes. The tubes were vortexed and placed in an ice-bath again for $15 \mathrm{~min}$. The assay tubes were then centrifuged $(13,000 \mathrm{rpm})$ for $10 \mathrm{~min}$ in a microcentrifuge mini spin Eppendorf $^{\circledR}$. Subsequently, $700 \mu \mathrm{L}$ of the supernatant and $300 \mu \mathrm{L}$ of a freshly prepared Nash reagent solution (Nash 1953) were transferred into all tubes that were incubated at $50^{\circ} \mathrm{C}$ for $30 \mathrm{~min}$. The absorbance was read at $412 \mathrm{~nm}$ on a Spectramax Plus microplate spectrophotometer (Molecular Devices ${ }^{\circledR}$ ) using the software Softmax Pro 4.0 for Macintosh ${ }^{\circledR}$ and Windows ${ }^{\circledR}$.

Determination of PZQ levels in blood plasma - Male and female mice of infected and CTRL mice matched control groups were treated with a single intraperitoneal injection of PZQ ( 200 or $400 \mathrm{mg} / \mathrm{kg}$ body weight) on PIDs 30 or 55 . Blood was taken from the orbital sinus and collected in ethylenediamine tetraacetic acid-coated vials at different post-treatment times $(5,15,30,60,90,120$ and $180 \mathrm{~min}$ ) before death by cervical dislocation. The plasma was separated by centrifugation.

Plasma concentrations of PZQ were determined by high-performance liquid chromatography (HPLC) using a Shimadzu LC-10Avp chromatographic system (Shimadzu, Kyoto, Japan) equipped with an autosampler (SIL$10 \mathrm{AF}$ ) and a diode array UV-Vis detector (SPD-M10AVP) operating at $217 \mathrm{~nm}$. The extraction procedure was carried out according to the methods described by Xiao et al. (1983) and Ridtitid et al. (2002), with some adaptations. Briefly, in a $1.5 \mathrm{~mL}$ stoppered microcentrifuge tube, $200 \mu \mathrm{L}$ of plasma, $25 \mu \mathrm{L}$ of diazepam (internal standard) solution at $240 \mu \mathrm{g} / \mathrm{mL}, 50 \mu \mathrm{L}$ of $0.2 \mathrm{M}$ zinc sulphate and $300 \mu \mathrm{L}$ of acetonitrile were vigorously mixed using a vortex mixer for $30 \mathrm{~s}$ and then centrifuged at $10,000 \mathrm{~g}$ for $10 \mathrm{~min}$. Fifty microliters of the supernatant was injected into the HPLC system by means of a pre-column Lichrospher 100 RP18 (4 x 4 mm, $5 \mu \mathrm{m})$ and a Lichrospher 100 RP-18 (125 x 4 mm, $5 \mu \mathrm{m})$ column (Merck) with water and acetonitrile $(58: 42, \mathrm{v} / \mathrm{v})$ as the mobile phase, at a flow rate of $1.5 \mathrm{~mL} / \mathrm{min}$. For validation of the method, the samples used for calibration and quality control were prepared in blank plasma. The analytical curve of the peak areas vs. concentrations of PZQ was found to be linear in the range of $0.7-44.0 \mu \mathrm{g} / \mathrm{mL}$, with a correlation coefficient of $\geq 0.999$. Under the experimental conditions used, the limit of detection was $0.23 \mu \mathrm{g} / \mathrm{mL}$, at a signal-to-noise ratio of $3: 1$, while the limit of quantification was $0.7 \mu \mathrm{g} / \mathrm{mL}$, defined as the lowest analyte concentration that could be measured with the stated level of confidence. The coefficients of variation (\%) of the intra and inter-day precisions for the determination of PZQ were lower than 5\%. The absolute recovery of PZQ in plasma was $99.5-101 \%$.

\section{RESULTS}

Infection and parasite egg recovery in the liver on PIDs 30 and 55 - As shown in Table I, skin penetration of $S$. mansoni cercariae was very efficient (96-100\%) in all experimental groups. No deaths and no other overt sign of illness were noted in infected mice. The parasite load used in this study (100 cercariae per animal) was apparently well tolerated by both male and female SW mice until PID 55 and no deaths were recorded among infected mice. While a relatively small number of parasite eggs was recovered from the livers of mice killed on PID 30, the number of recovered eggs dramatically increased in animals that were killed 25 days later (i.e., on PID 55) (Table I). The foregoing results are consistent with findings from previous studies (Fidalgo-Neto et al. 2004, Manhães-Rocha et al. 2005) and indicated that, in this murine model of schistosomiasis, worms attain sexual maturity and start laying eggs approximately one month after infection.

Expression of CYP1A2, $2 E 1$ and $3 A 11 \mathrm{mRNAs}$ in the liver tissue - On PID 55, levels of CYP1A2, 2E1 and 3A11 mRNAs in liver tissue were markedly depressed in both male and female $S$. mansoni-infected mice as compared to levels recorded in CTRL mice of the same gender (Figs 1-3). The effect of early $S$. mansoni infection on the levels of CYP mRNAs, however, is dependent on the sex of the

\section{TABLE I}

Skin penetration of Schistosoma mansoni cercariae and recovery of worm eggs in the liver of male and female Swiss Webster mice on post-infection days (PIDs) 30 and 55

\begin{tabular}{lcccc}
\hline PIDs & & 30 & & 55 \\
\hline Sex & Male & Female & Male & Female \\
\hline Skin penetration (\%) & $100(96-100)$ & $100(98-100)$ & $100(97-100)$ & $100(98-100)$ \\
Exposed mice (n) & 80 & 80 & 78 & 80 \\
Liver weight (g) & $2.35 \pm 0.26$ & $1.88 \pm 0.16$ & $3.20 \pm 0.50$ & $3.25 \pm 0.53$ \\
Eggs trapped in the liver (n x 10 & $0.51 \pm 0.29$ & $0.62 \pm 0.42$ & $20.55 \pm 12.57$ & $17.31 \pm 13.91$ \\
Examined livers (n) & 17 & 15 & 78 & 80
\end{tabular}

values are median and range (skin penetration) or mean \pm standard deviation (liver weight and eggs trapped in the liver). Mice were exposed to 100 cercariae on post-natal day 10. Liver weights (g) of non-infected controls were as follows: PID 30: males, $2.27 \pm 0.10$, females, $1.52 \pm 0.20$; PID 55: males, $2.04 \pm 0.07$, females, $1.71 \pm 0.08$. 
CYP1A2
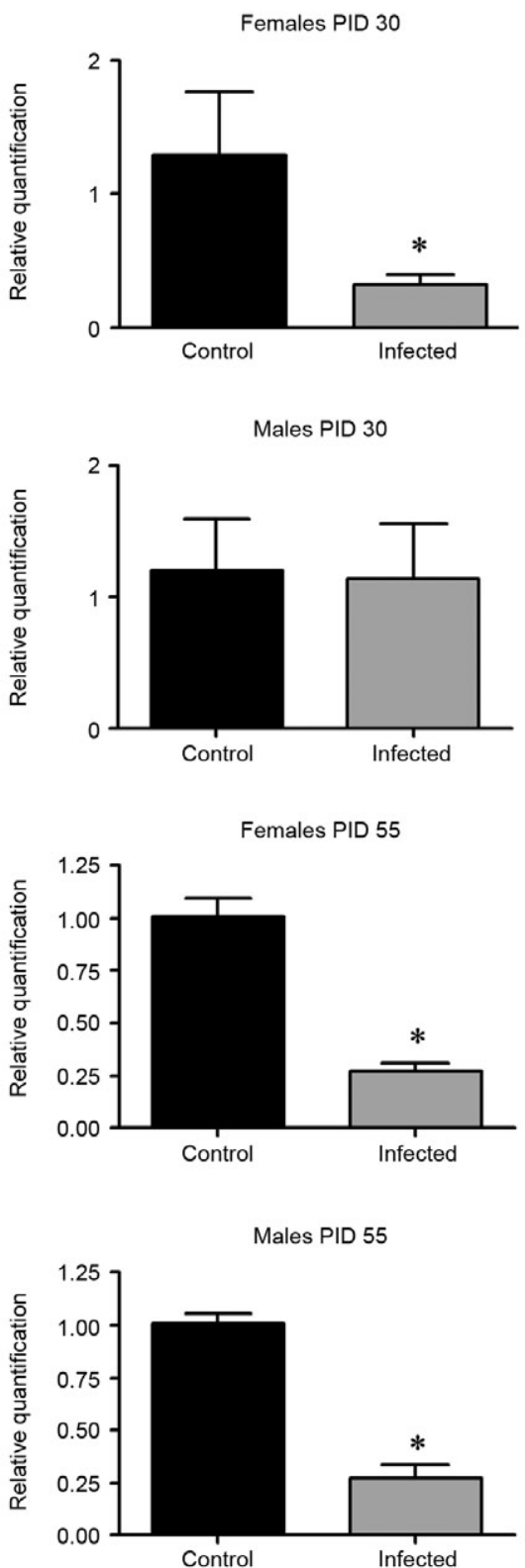

Fig. 1: expression of cytochrome P450 (CYP) 1A2 mRNA in the liver of male and female mice 30 and 55 days after infection with Schistosoma mansoni [post-infection days (PIDs) 30 and 55]. Column height represents mean \pm standard deviation for relative levels of mRNA of four Swiss Webster mice. Differences $(* p<0.01)$ between infected and non-infected control mice were analyzed by the Student's $t$ test. Mice were infected with 100 cercariae on postnatal day 10. Controls were non-infected mice of the same gender and age. Quantification of mRNA was performed by real time reverse transcription-polymerase chain reaction.

mouse. On PID 30, levels of CYP1A2 and 2E1 mRNAs were depressed in infected females mice as compared with CTRL female mice (Figs 1, 2). Levels of CYP3A11 mRNA were also observed to be lower in infected female mice as compared with CTRL mice; however, in
CYP2E1
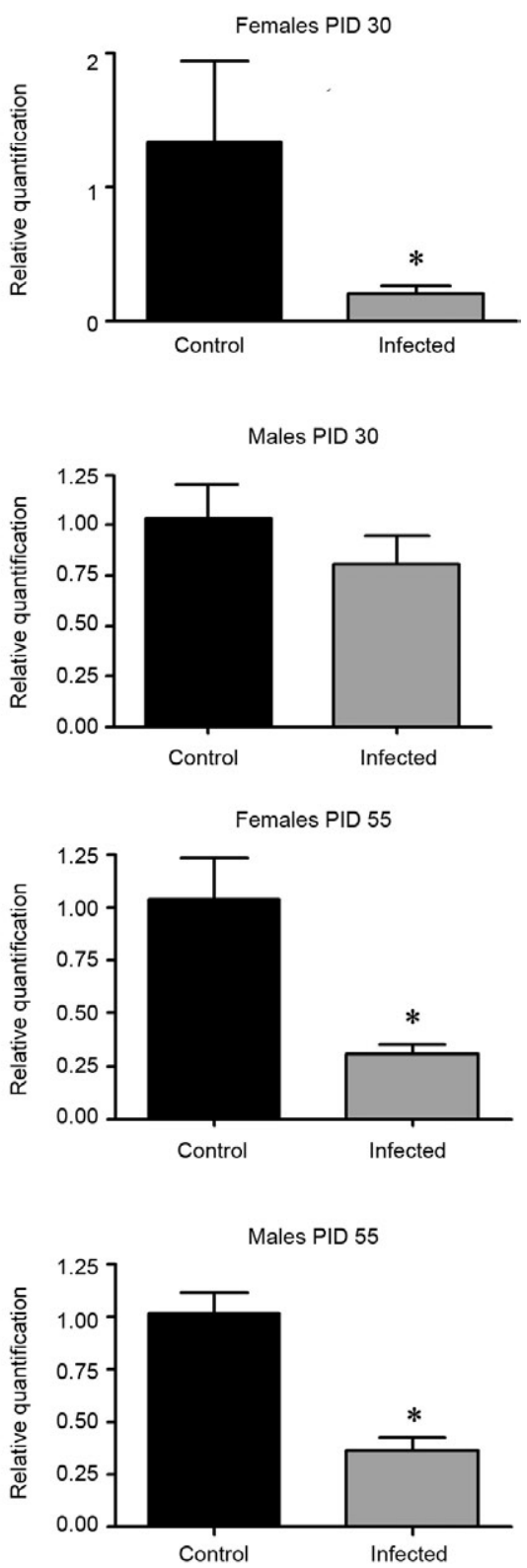

Fig. 2: expression of cytochrome P450 (CYP) 2E1 mRNA in the liver of male and female mice 30 and 55 days after infection with Schistosoma mansoni [post-infection days (PIDs) 30 and 55]. Column height represents mean \pm standard deviation for relative levels of mRNA of four Swiss Webster mice. Differences $\left({ }^{*} p<0.01\right)$ between infected and non-infected control mice were analyzed by the Student's $t$ test. Mice were infected with 100 cercariae on postnatal day 10. Controls were non-infected mice of the same gender and age. Quantification of mRNA was performed by real time reverse transcription-polymerase chain reaction.

this case, the difference was not statistically significant (Fig. 3). In contrast with the early S. mansoni infectioncaused depression of CYP mRNA levels in female mice, the expression of CYP mRNAs remained unaltered in the liver of infected male mice on PID 30 (Figs 1-3). 

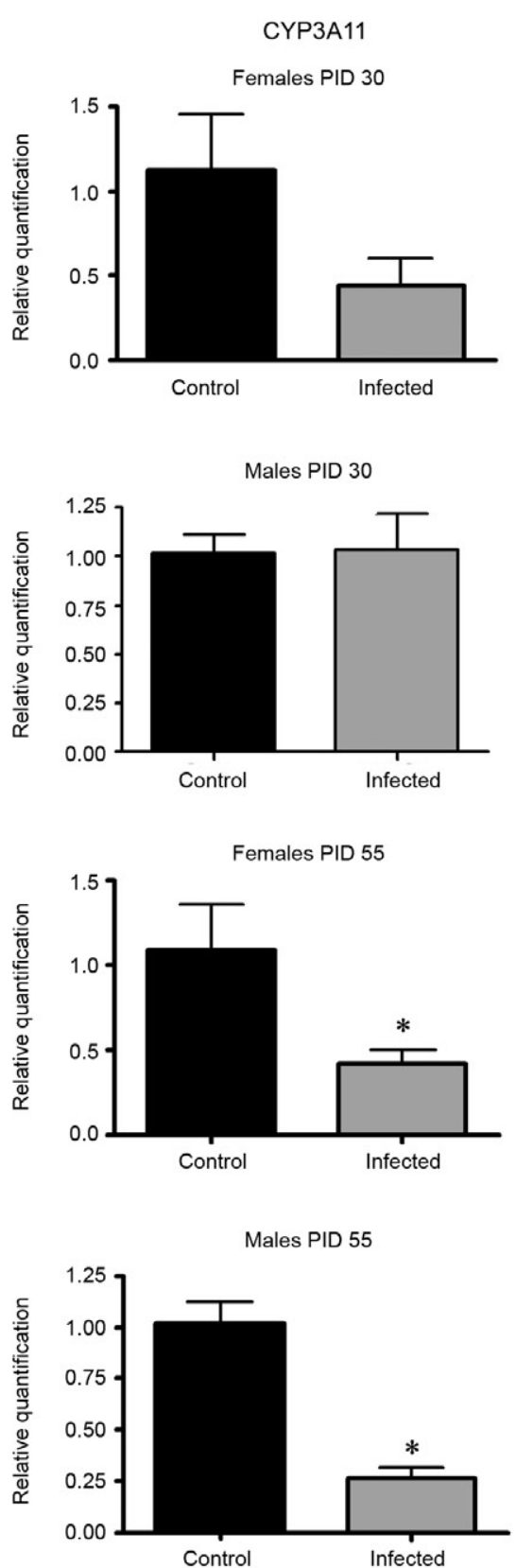

Fig. 3: expression of cytochrome P450 (CYP) 3A11 mRNA in the liver of male and female mice 30 and 55 days after infection with Schistosoma mansoni [post-infection days (PIDs) 30 and 55]. Column height represents mean \pm standard deviation for relative levels of mRNA of four Swiss Webster mice. Differences $(* p<0.01)$ between infected and non-infected control mice were analyzed by the Student's $t$ test. Mice were infected with 100 cercariae on postnatal day 10. Controls were non-infected mice of the same gender and age. Quantification of mRNA was performed by real time reverse transcription-polymerase chain reaction.

Activity of monooxygenases in the liver microsomal fraction - The effects of S. mansoni infection on the activity of liver monooxygenase reactions mediated by CYP1A1/2 (EROD, MROD), 2B9/10 (BROD, PROD), 2E1 (PNPH) and 3A11 (END) are shown in Table II. On PID 30, no dif- ferences of hepatic monooxygenase activity between infected and CTRL mice were observed, both among males and females. Twenty-five days later (PID 55), however, $S$. mansoni infection markedly depressed the activities catalyzed by CYP1A1/2, 2B9/10 and 2E1 in liver microsomes from male and female mice. On PID 55, the activity of CYP3A11 (END) was depressed in microsomes from infected male mice; however, the activity remained nearly unaltered in infected female mice (Table II).

Pharmacokinetics and toxicity of PZQ on PIDs 30 and 50 - The effects of infection on the kinetics and toxicity of PZQ [200 or $400 \mathrm{mg} / \mathrm{kg}$ body weight intraperitoneally (i.p.)] were examined in $S$. mansoni-infected mice on PIDs 30 and 55 (Figs 4, 5). In CTRL mice, the lowest dose of PZQ (200 mg/kg body wt i.p.) gave rise to maximal plasma concentrations as high as $28.2 \mu \mathrm{g} / \mathrm{mL}$ (PID 30) and $26.5 \mu \mathrm{g} / \mathrm{mL}$ (PID 55) in males (Fig. 4) and $33.6 \mu \mathrm{g} /$ $\mathrm{mL}$ (PID 30) and $26.9 \mu \mathrm{g} / \mathrm{mL}$ (PID 55) in females (Fig. 5), 15 min after drug administration. Maximum plasma levels found in CTRL mice treated with the highest dose of PZQ ( $400 \mathrm{mg} / \mathrm{kg}$ body wt i.p.) were $36.1 \mu \mathrm{g} / \mathrm{mL}$ (PID 30) and $31.8 \mu \mathrm{g} / \mathrm{mL}$ (PID 55) in males (Fig. 4) and $54.4 \mu \mathrm{g} /$ $\mathrm{mL}$ (PID 30) and $47.4 \mu \mathrm{g} / \mathrm{mL}$ (PID 55) in females (Fig. 5), 15 min after drug administration. On PID 30, both CTRL and infected mice rapidly eliminated PZQ so that in males and females plasma levels of the parent compound were nearly zero 90 (200 mg/kg i.p.) or $180 \mathrm{~min}(400 \mathrm{mg} / \mathrm{kg}$ i.p.) after treatment with PZQ, (Figs 4, 5). At this early stage of infection (PID 30), there was no discernible difference between infected and CTRL mice regarding PZQ area under the curve (AUC) ( $\mu \mathrm{g} \cdot \mathrm{mL}^{-1}$.min) determined after administration of doses as high as $200 \mathrm{mg} / \mathrm{kg}$ body weight (M: infected $=1,179, \mathrm{CTRL}=1,059 ; \mathrm{F}$ : infected $=2,435, \mathrm{CTRL}$ $=1,746)$ and $400 \mathrm{mg} / \mathrm{kg}$ body weight $(\mathrm{M}$ : infected $=3,462$, $\mathrm{CTRL}=2,579$; F: infected $=6,863, \mathrm{CTRL}=5,792)$. Nevertheless, on PID 55, the PZQ clearance in infected mice was slower than the clearance in CTRL mice (Figs 4, 5). At this more advanced stage of $S$. mansoni infection, the AUC ( $\mu$ g.mL $\left.\mathrm{mL}^{-1} . \mathrm{min}\right)$ values for plasma PZQ levels against time in infected mice ( $200 \mathrm{mg} / \mathrm{kg}$ body weight: $\mathrm{M}=4,861$, $\mathrm{F}=4,610 ; 400 \mathrm{mg} / \mathrm{kg}$ body weight: $\mathrm{M}=7,968, \mathrm{~F}=8,761$ ) were higher than the corresponding values for CTRL mice $(200 \mathrm{mg} / \mathrm{kg}$ body weight: $\mathrm{M}=1,139, \mathrm{~F}=1,592$; $400 \mathrm{mg} / \mathrm{kg}$ body weight: $\mathrm{M}=1,990, \mathrm{~F}=4,696)$. On PID 55 , infected mice also proved to be more susceptible to PZQ-induced toxicity than CTRL mice. On PID 30, no toxic effects of PZQ were noted in CTRL and infected mice. On PID 55, while producing a marked hypnotic effect and several deaths among the $S$. mansoni-infected mice, the highest dose of PZQ caused no overt toxicity in CTRL mice.

\section{DISCUSSION}

On PID 55, when a large number of $S$. mansoni eggs were retained in the liver, CYP1A1/2 (EROD/MROD), 2B9/10 (PROD/BROD), 2E1 (PNPH) and 3A11 (END)mediated activities were all markedly depressed in the hepatic microsomes from both male and female mice. Interestingly, no alterations of CYP-mediated activities were noted 25 days earlier (PID 30) when very few eggs, 
TABLE II

Activity of liver monooxygenases in Swiss Webster mice infected with Schistosoma mansoni and their non-infected controls on post-infection days (PIDs) 30 and 55

\begin{tabular}{|c|c|c|c|c|c|c|c|c|}
\hline \multirow{3}{*}{$\begin{array}{l}\text { Infection group } \\
\text { PIDs } \\
\text { Sex }\end{array}$} & \multicolumn{2}{|c|}{ Control } & \multicolumn{2}{|c|}{ Infected } & \multicolumn{2}{|c|}{ Control } & \multicolumn{2}{|c|}{ Infected } \\
\hline & \multicolumn{4}{|c|}{30} & \multicolumn{4}{|c|}{55} \\
\hline & Male & Female & Male & Female & Male & Female & Male & Female \\
\hline Liver enzyme activity & Mean \pm SD & Mean \pm SD & Mean \pm SD & Mean \pm SD & Mean \pm SD & Mean \pm SD & Mean \pm SD & Mean \pm SD \\
\hline XROD (pmol/mg ptn/ min) & (n) & (n) & (n) & (n) & (n) & (n) & (n) & (n) \\
\hline EROD & $\begin{array}{c}154.7 \pm 21 \\
(8)\end{array}$ & $\begin{array}{c}78.2 \pm 4.3 \\
(9)\end{array}$ & $\begin{array}{c}140 \pm 14.7 \\
(10)\end{array}$ & $\begin{array}{c}87.3 \pm 7.3 \\
(10)\end{array}$ & $\begin{array}{c}122.5 \pm 9.3 \\
(8)\end{array}$ & $\begin{array}{c}81.6 \pm 5.5 \\
(10)\end{array}$ & $\begin{array}{c}42.1 \pm 6.2^{a} \\
(8)\end{array}$ & $\begin{array}{c}32.8 \pm 3.7^{a} \\
(10)\end{array}$ \\
\hline MROD & $\begin{array}{c}226 \pm 19 \\
(4)\end{array}$ & $\begin{array}{c}149 \pm 41 \\
(4)\end{array}$ & $\begin{array}{c}208 \pm 17 \\
(4)\end{array}$ & $\begin{array}{c}133 \pm 13 \\
(8)\end{array}$ & $\begin{array}{c}110 \pm 7.4 \\
(8)\end{array}$ & $\begin{array}{c}62.7 \pm 4.2 \\
(10)\end{array}$ & $\begin{array}{c}36 \pm 4.3^{a} \\
(8)\end{array}$ & $\begin{array}{c}28.5 \pm 6.1^{a} \\
(10)\end{array}$ \\
\hline PROD & $\begin{array}{c}15.3 \pm 1.7 \\
(8)\end{array}$ & $\begin{array}{c}18.6 \pm 1.7 \\
\text { (9) }\end{array}$ & $\begin{array}{c}15.8 \pm 1.2 \\
(10)\end{array}$ & $\begin{array}{c}16.8 \pm 1.1 \\
(10)\end{array}$ & $\begin{array}{c}12.4 \pm 1.8 \\
(8)\end{array}$ & $\begin{array}{c}22.09 \pm 1.4 \\
(10)\end{array}$ & $\begin{array}{c}4.9 \pm 0.3^{a} \\
(8)\end{array}$ & $\begin{array}{c}5.3 \pm 0.6^{a} \\
(10)\end{array}$ \\
\hline BROD & $\begin{array}{c}43.7 \pm 1.7 \\
(7)\end{array}$ & $\begin{array}{c}61 \pm 10 \\
(9)\end{array}$ & $\begin{array}{c}52.4 \pm 9.1 \\
(10)\end{array}$ & $\begin{array}{c}49 \pm 6.8 \\
(10)\end{array}$ & $\begin{array}{c}23 \pm 3 \\
(6)\end{array}$ & $\begin{array}{c}61 \pm 12 \\
(10)\end{array}$ & $\begin{array}{c}4.8 \pm 1.5^{a} \\
(8)\end{array}$ & $\begin{array}{c}5.2 \pm 1.0^{a} \\
(10)\end{array}$ \\
\hline PNPH & $3.8 \pm 0.5$ & $2.2 \pm 0.17$ & $5.3 \pm 0.7$ & $1.8 \pm 0.2$ & $2.3 \pm 0.15$ & $3.1 \pm 0.7$ & $1.65 \pm 0.2^{a}$ & $1.5 \pm 0.2^{a}$ \\
\hline (nmol/mg ptn/ min) & (7) & (9) & (7) & (10) & (8) & (9) & (8) & (10) \\
\hline END & $1.7 \pm 0.3$ & $1.1 \pm 0.2$ & $1.9 \pm 0.1$ & $1.2 \pm 0.3$ & $0.7 \pm 0.03$ & $0.9 \pm 0.08$ & $0.4 \pm 0.07^{a}$ & $0.7 \pm 0.09$ \\
\hline (nmol/mg ptn/ min) & (7) & (9) & (7) & (10) & $(8)$ & (8) & (8) & (9) \\
\hline
\end{tabular}

$a$ : different $(\mathrm{p}<0.05)$ from controls of the same gender killed on the same PID; BROD: benzyloxy resorufin- $O$-debenzylase; END: erythromycin-N-demethylase; EROD: ethoxy resorufin- $O$-deethylase; MROD: methoxy-resorufin- $O$-demethylase; PNPH: $p$-nitrophenol-hydroxylase; PROD: pentoxy resorufin- $O$-depenthylase; SD: standard deviation; XROD: alcoxyresorufin- $O$-dealkylases. Uninfected controls were sex and age-paired.

if any, were recovered from the livers of the mice. The aforementioned findings were thus consistent with the prevailing view that the depression of CYP activities observed in infected mice arises from the inflammatory reaction (granuloma) around parasite eggs deposited in the liver (Manhães-Rocha et al. 2005, Conte et al. 2007). Because the hydroxylation of PZQ in the mammalian liver is catalyzed predominantly by CYP3A enzymes (Masimirembwa \& Hasler 1994, Li et al. 2003), results showing that the clearance of PZQ was unaltered on PID 30 , but drastically reduced by PID 55, were also consistent with this interpretation.

Furthermore, the depression of CYP activities caused by $S$. mansoni infection seemed to have arisen from a lower transcription and/or from a faster degradation of mRNAs, because levels of CYP1A2, 2E1 and 3A11 mRNAs in infected mice were markedly lower than the corresponding levels in CTRL mice. Although a variety of infections and pro-inflammatory stimuli have been shown to depress the activity of liver CYPs, their effects on the expression of CYP mRNAs have seldom been investigated. It has been found that CYP mRNA levels in the liver of rats and mice are depressed by treatment with Escherichia coli lipopolisacharide (Morgan et al. 2002). Along the same vein, it was also reported that Plasmodium berghei malaria depresses levels of CYP mRNA and protein as well as CYP-mediated activities in the liver of infected mice (Carvalho et al. 2009). Taken together, results presented here and those from the aforementioned studies suggested that pro-inflammatory stimuli and infections down-regulate the expression and activity of hepatic CYPs at a pretranslational level, i.e., by decreasing gene transcription and/or mRNA stability. Data provided by this study showed that 30 days after infection (PID 30), CYP activities and mRNA levels in the liver, as well as the clearance of PZQ, remained unaltered in male mice. In females, however, while enzyme activities and PZQ clearance were still unaltered, the expression of CYP mRNAs was already downregulated on PID 30. The foregoing findings indicated that as far as the decline of liver CYP mRNA levels is concerned, the response to $S$. mansoni infection started somewhat earlier in females than in males. The latency of the reduction in enzyme activity after an infectionelicited depression of CYP mRNA levels depends on the protein turnover rate. At any rate, the timing of these early changes of CYP mRNA expression noted in infected female mice is consistent with the view that the down-regulation of CYPs begins when worms reach sexual maturity. Noticeably, very few parasite eggs were recovered from the livers of infected females mice on PID 30. Thus the decline of CYP mRNA levels may have been due to systemic changes triggered at the beginning of worm oviposition on PID 30 rather than by the development of a local inflammatory reaction (granulomas) around the eggs. 
PID 30
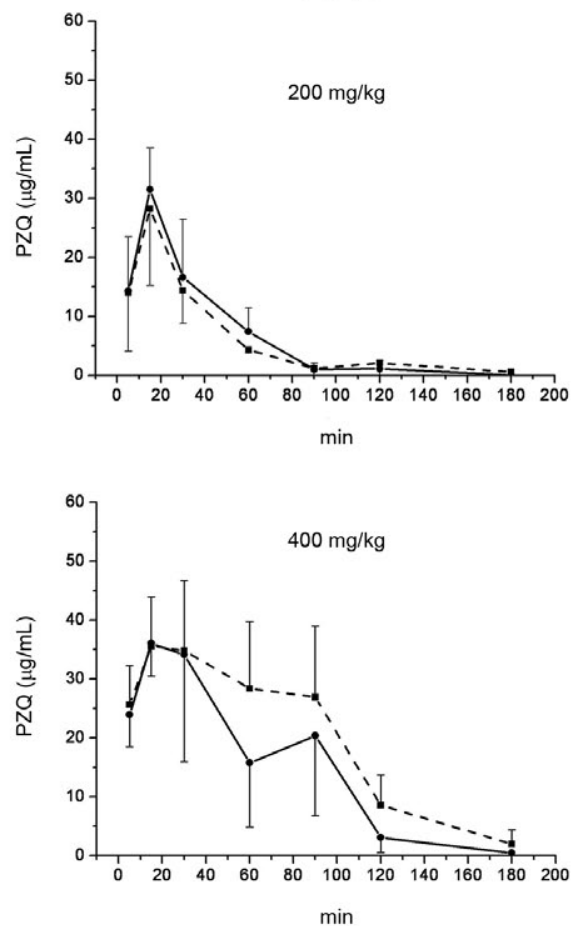

PID 55

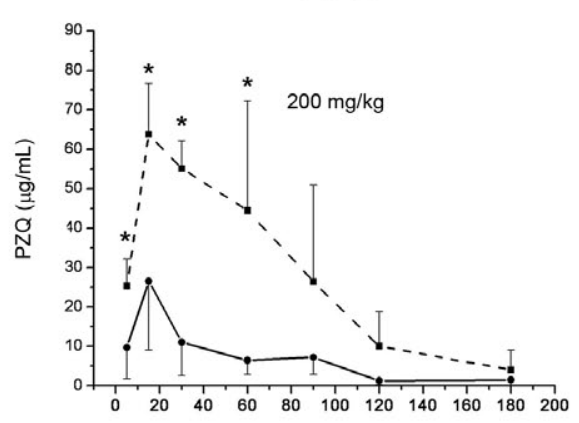

$\min$

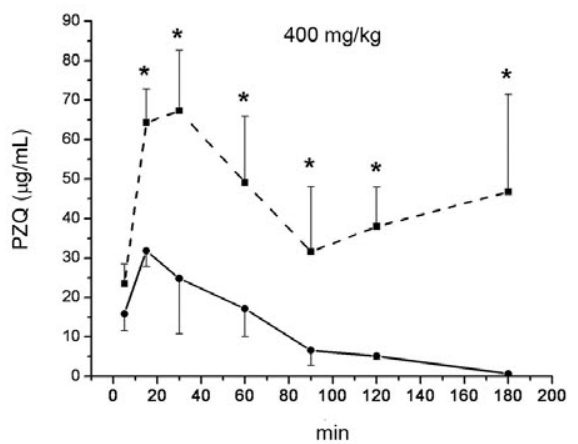

Fig. 4: effects of Schistosoma mansoni infection on the pharmacokinetics of praziquantel (PZQ) in male Swiss Webster mice. Infected mice and their non-infected matched controls were injected with PZQ (200 or $400 \mathrm{mg} / \mathrm{kg}$ body weight intraperitoneally) on post-infection days (PIDs) 30 or 55 and plasma levels were determined at different post-treatment intervals. Each value is the mean \pm standard error of the means of a distinct group of 7-10 mice. Differences $(* p<0.05)$ between infected (solid lines and circles) and non-infected control (dashed lines and squares) mice were analyzed by the Student's $t$ test.
PID 30
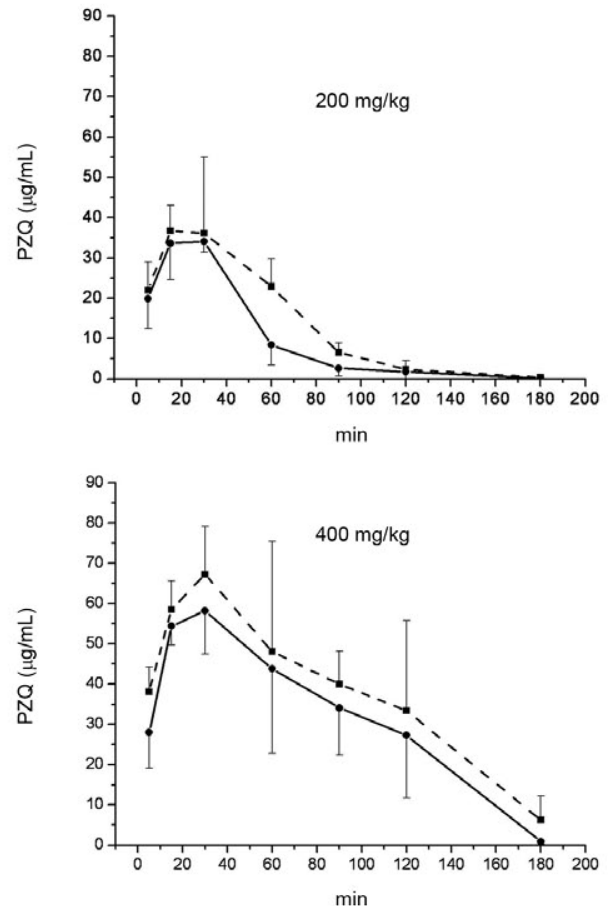

PID 55
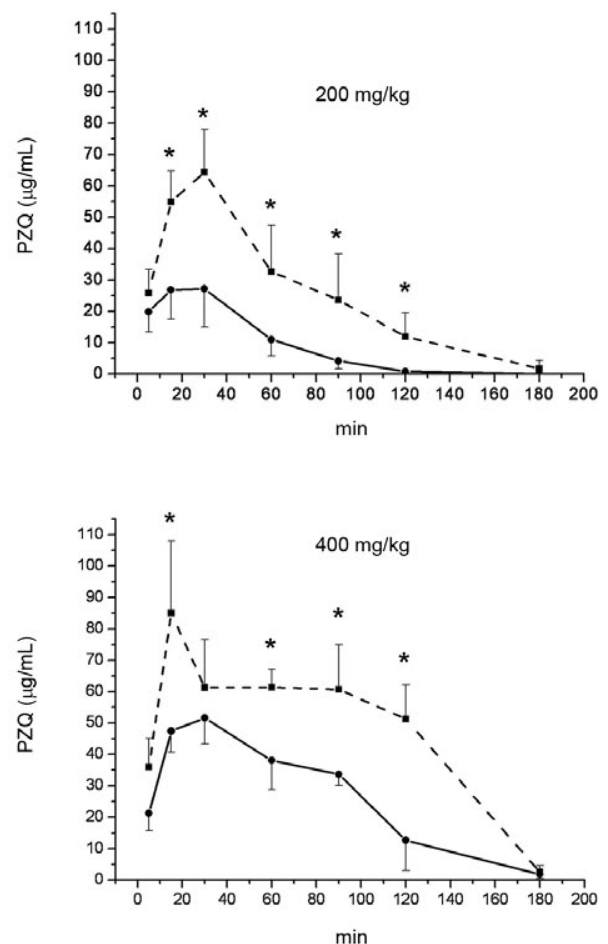

Fig. 5: effects of Schistosoma mansoni infection on the pharmacokinetics of praziquantel (PZQ) in female Swiss Webster mice. Infected mice and their non-infected matched controls were injected with PZQ (200 or $400 \mathrm{mg} / \mathrm{kg}$ body weight intraperitoneally) on post-infection days (PIDs) 30 or 55 and plasma levels were determined at different post-treatment intervals. Each value is the mean \pm standard error of the means of a distinct group of 7-10 mice. Differences $\left({ }^{*} p<0.05\right)$ between infected (solid lines and circles) and non-infected control (dashed lines and squares) mice were analyzed by the Student's $t$ test. 
As expected, the schistosomiasis-elicited downmodulation of liver CYP activities resulted in alterations of drug kinetics in the infected host. The slower clearance of PZQ in infected mice, as compared to the clearance in CTRL mice, is consistent with the view that PZQ is converted into its primary metabolite (PZQ-OH) by CYP2B and 3A enzymes (Godawska-Matysik \& KiećKononowicz 2006), the activities of which were markedly depressed by schistosomiasis. Central nervous system depression and deaths noted among mice treated with PZQ (400 $\mathrm{mg} / \mathrm{kg}$ body weight) on PID 55 were due to the higher $\mathrm{C}_{\max }$ and larger AUCs of PZQ in infected mice.

This study suggested that the kinetics of PZQ, today's drug of choice for treating trematode infections, and possibly also that of other drugs, can be markedly altered during the course of $S$. mansoni infections. It remains to be further evaluated, however, whether liver CYPs are down-modulated during human infections and, if so, whether these changes of CYP expression can give rise to clinically relevant alterations of drug kinetics. As far as we are aware, there is no on-going study of the effects of schistosomiasis on human drug metabolism. Results reported by Masimirembwa et al. (1995), however, were consistent with the view that a down-regulation of CYP occurs in infected humans as well. According to the authors, children living in a rural area of Zimbabwe (Shona children) where schistosomiasis is endemic exhibited a low activity of CYP1A2 (measured by using caffeine as a probe). In contrast, activities of xanthine oxidase and $\mathrm{N}$-acetyl-transferase, which are non-CYP enzymes, were comparable to those found in children from nonendemic regions (Masimirembwa et al. 1995).

\section{ACKNOWLEDGEMENTS}

To Dr Sergio N Kuriyama, Department of Biological Sciences-Fiocruz, for assistance on data analysis, and to Dr Ligia Reis Correa, Department of Malacology-Fiocruz, for supplying the $S$. mansoni cercariae used in this study.

\section{REFERENCES}

Allis JW, Robinson BL 1994. A kinetic assay for $p$-nitrophenol hydroxylase in rat liver microsomes. Anal Biochem 219: 49-52.

Berg-Candolfi M, Candolfi E 1996. Depression of the N-demethylation of erythromycin, azithromycin, clarithromycin and clindamycin in murine Toxoplasma infection. Int J Parasitol 26: 1321-1323.

Bradford MM 1976. A rapid and sensitive method for the quantitation of microgram quantities of protein utilizing the principle of protein-dye binding. Anal Biochem 72: 248-254.

Burke MD, Thompson S, Elcombe CR, Halpert J, Haaparanta T, Mayer RT 1985. Ethoxy-, pentoxy- and benzyloxyphenoxazones and homologues: a series of substrates to distinguish between different induced cytochromes P-450. Biochem Pharmacol 34: 3337-3345.

Carvalho RS, Friedrich K, De-Oliveira AC, Suarez-Kurtz G, Paumgartten FJ 2009. Malaria downmodulates mRNA expression and catalytic activities of CYP1A2, 2E1 and 3A11 in mouse liver. Eur J Pharmacol 616: 265-269.

Cha YN, Byram JE, Heine HS, Bueding E 1980a. Effect of Schistosoma mansoni infection on hepatic drug-metabolizing capacity of athymic nude mice. Am J Trop Med Hyg 29: 234-238.

Cha YN, Edwards R 1976. Effect of Schistosoma mansoni infection on the hepatic drug-metabolizing capacity of mice. J Pharmacol Exp Ther 199: 432-440.
Cha YN, Heine HS, Bueding E 1980b. Effect of unisexual Schistosoma mansoni infections on hepatic drug metabolism of mice. Am J Trop Med Hyg 29: 227-233.

Cheever AW 1968. Conditions affecting the accuracy of potassium hydroxide digestion techniques for counting Schistosoma mansoni eggs in tissues. Bull World Health Organ 39: 328-331.

Conte FP, Fidalgo-Neto AA, Manhães-Rocha DA, Paumgartten FJ, De-Oliveira AC 2007. Activity of liver microsomal enzymes during the chronic phase of murine schistosomiasis. Braz J Med Biol Res 40: 657-662.

De-Oliveira AC, Fidalgo-Neto AA, Paumgartten FJ 1999. In vitro inhibition of liver monooxygenases by beta-ionone, 1,8-cineole, (-)-menthol and terpineol. Toxicology 135: 33-41.

El-Bassiouni EA, Mostafa MH, El-Sewedy SM, El-Meligy S, AbdelAziz T, Abdel-Rafee A 1984. Hepatic microsomal enzymes in S. mansoni-infected mice. II. Effect of duration of infection and lindane administration on aminopyrine demethylase and aniline hydroxylase. J Environ Sci Health B 19: 193-207.

Fidalgo-Neto AA, De-Carvalho RR, De-Oliveira ACAX, ManhãesRocha DA, Paumgartten FJR 2004. Penetration and maturation of Schistosoma mansoni in suckling and adult Swiss Webster and DBA/2 mice. J Exp Anim Sci 43: 29-38.

Fried B, Reddy A, Mayer D 2010. Helminths in human carcinogenesis. Cancer Lett: doi:10.1016/j.canlet.2010.07.008.

Godawska-Matysik A, Kieć-Kononowicz K 2006. Biotransformation of praziquantel by human cytochrome p450 3A4 (CYP 3A4). Acta Pol Pharm 63: 381-385.

Gryseels B, Polman K, Clerinx J, Kestens L 2006. Human schistosomiasis. Lancet 368: 1106-1118.

Li XQ, Björkman A, Andersson TB, Gustafsson LL, Masimirembwa CM 2003. Identification of human cytochrome $P(450)$ s that metabolise anti-parasitic drugs and predictions of in vivo drug hepatic clearance from in vitro data. Eur J Clin Pharmacol 59: 429-442.

Manhães-Rocha DA, Conte FP, Fidalgo-Neto AA, De-Oliveira AC, Ribeiro-Pinto LF, Paumgartten FJ 2005. Alterations of hepatic microsomal enzymes in the early phase of murine schistosomiasis. Acta Trop 95: 58-66.

Masimirembwa CM, Beke M, Hasler JA, Tang BK, Kalow W 1995. Low CYP1A2 activity in rural Shona children of Zimbabwe. Clin Pharmacol Ther 57: 25-31.

Masimirembwa CM, Hasler JA 1994. Characterisation of praziquantel metabolism by rat liver microsomes using cytochrome P450 inhibitors. Biochem Pharmacol 48: 1779-1783.

Morgan ET, Li-Masters T, Cheng PY 2002. Mechanisms of cytochrome $\mathrm{P} 450$ regulation by inflammatory mediators. Toxicology 181-182: 207-210.

Mostafa MH, el-Bassiouni EA, el-Sewedy SM, Akhnouk S, Tawfic T, Abdel-Rafee A 1984. Hepatic microsomal enzymes in Schistosoma mansoni-infected mice. I. Effect of duration of infection and lindane administration on dimethylnitrosamine demethylases. Environ Res 35: 154-159.

Nash T 1953. The colorimetric estimation of formaldehyde by means of the Hantzsch reaction. Biochem J 55: 416-421.

Ridtitid W, Wongnawa M, Mahatthanatrakul W, Punyo J, Sunbhanich M 2002. Rifampin markedly decreases plasma concentrations of praziquantel in healthy volunteers. Clin Pharmacol Ther 72: 505-513.

Sheweita SA, Mangoura SA, el-Shemi AG 1998. Different levels of Schistosoma mansoni infection induce changes in drug-metabolizing enzymes. $J$ Helminthol 72: 71-77.

Xiao SH, Catto BA, Webster LT Jr 1983. Quantitative determination of praziquantel in serum by high-performance liquid chromatography. J Chromatogr 275: 127-132. 